\title{
Political-ethical skill development in nursing undergraduates
}

\author{
O DESENVOLVIMENTO DE COMPETÊNCIAS ÉTICO-POLÍTICAS SEGUNDO EGRESSOS \\ DE UM CURSO DE GRADUAÇÃO EM ENFERMAGEM
}

\section{EL DESARROLLO DE COMPETENCIAS ÉTICO-POLÍTICAS SEGÚN EGRESADOS DE UN CURSO DE PRE-GRADO EN ENFERMERÍA}

\author{
Maria Dyrce Dias Meira', Paulina Kurcgant ${ }^{2}$
}

\begin{abstract}
This research aimed to identify political-ethical skills developed in a training process compatible with the expected profile set by the National Curriculum Guidelines for the Undergraduate Nursing Degree. A case study was conducted with units represented by 32 former students from a particular religious teaching institution who already were in the job market. The content of the interviews was analyzed using the thematic analysis technique, which resulted in the following categories: Political-ethical skills in the formative process and Political-ethical skills as a product of the educational process. From the former students' perspective, these categories reinforced the social role of the nurse and the need for students to be reflective, understanding and participative in the transformation of society.
\end{abstract}

\section{DESCRIPTORS}

Education, nursing

Professional competence

Learning;

Curriculum

Ethics, nursing

\section{RESUMO}

Esta pesquisa teve como objetivo identificar competências ético-políticas possibilitadas pelo processo formativo compatíveis com o perfil do enfermeiro previsto nas Diretrizes Curriculares Nacionais para os Cursos de Graduação em Enfermagem. É um estudo de caso com unidades incorporadas representadas por 32 egressos de uma instituição de ensino particular confessional e inseridos no mercado de trabalho. $O$ conteúdo das entrevistas foi analisado com base na técnica da Análise Temática resultando nas categorias: Competências ético-políticas no processo formativo e Competências ético-políticas como produto do processo formativo. $\mathrm{Na}$ perspectiva do egresso, estas categorias reforçam o papel social do profissional enfermeiro e o preparo do estudante para a reflexão, a compreensão e a participação na transformação da sociedade.

\author{
DESCRITORES \\ Educação em enfermagem \\ Competência profissional \\ Aprendizagem \\ Currículo \\ Ética em enfermagem
}

\section{RESUMEN}

Esta investigación tuvo como objetivo identificar las competencias ético-políticas desarrolladas en la formación del enfermero, compatibles con el perfil previsto en las Directrices Curriculares Nacionales para los cursos de pregrado en Enfermería. Es un estudio de caso, con unidades incorporadas representadas por 32 egresados de una Institución de Enseñanza particular confesional e incorporados al mercado laboral. El contenido de las entrevistas fue analizado bajo la técnica de Análisis Temático, resultando en las Categorías: Competencias ético-políticas en el proceso de formación y Competencias ético-políticas como producto del proceso de formación. Desde la perspectiva del egresado, estas categorías refuerzan el papel social del profesional enfermero y la preparación del estudiante para reflexionar, comprender y participar en la transformación de la sociedad.

\section{DESCRIPTORES \\ Educación en enfermería \\ Competencia profesional \\ Aprendizaje \\ Curriculum \\ Ética en enfermería}

\footnotetext{
${ }^{1}$ Nurse. Doctorate in Sciences by the University of São Paulo School of Nursing. Professor in Nursing Undergraduate Course of the São Paulo Adventist University Center, São Paulo, SP, Brazil. dyrcem@yahoo.com.br ${ }^{2}$ Nurse. Full Professor at the University of São Paulo School of Nursing. São Paulo, SP. Brazil. pkurcg@usp.br
} 


\section{INTRODUCTION}

Eln line with the proposals of the National Curriculum Guidelines - NCG ${ }^{(1)}$, nursing education advocated for a

qualified professional for nursing practice, based on scientific and intellectual rigor and on ethical principles, able to work with social responsibility, citizenship commitment and as a promoter of the health of the human being.

Nursing schools have as their mission an alignment of their political-pedagogical proposals to this expected profile and to implement their educational practice in this direction.

Human activity in any social group always has a political character, since living in society integrates interests and intentions from both personal and collective spheres. On the other hand, the ethical principles and values should guide actions and decisions of nurses, ensuring promotion, protection, recovery and rehabilitation of health. In the conduct of daily activities, such values provide a framework that supports the autonomy of nurses ${ }^{(2)}$.

Despite the interrelation of technical, scientific, social, educational and politicalethical competences in the daily exercise of nursing practice, the development of political-ethical skills remains a challenge for education. For the protagonists to contruct comprehensive health care, recommended as one of the guiding principles of the Unified Health System (SUS), it is imperative for nurses to possess certain knowledge, skills and attitudes, for them to deliver a competent practice. In this context,

being competent is to re-order the relationship between work and education, which is the center of their praxis, enhancing health actions while recognizing subjectivities and ethical issue ${ }^{(3)}$.

The concept of competence that underlies this study makes reference to:

The taking of initiative and responsibility, the practical intelligence of some situations, which relies on acquired knowledge and the ability to transform and mobilize networks of actors around the same situations, and co-responsibility and a sense of sharing for what comes into play in each situation ${ }^{(4)}$.

This multidimensional perspective situates the competencies among the qualification and the professional experience. For a better understanding of the term political-ethical competencies it is noteworthy that the etymological root of the word ethics comes from the Greek ethos, understood as mode of being or character that expresses the sense of a norm, something expressing what should be. In turn, the word politics, also from the Greek polis, means city, or everything that relates to citizenship, that is to say: all concerns, discussions and decisions involving the city ${ }^{(5)}$.

In nursing practice, political-ethical competencies are conceptualized as the ability to collectively construct work processes; to decide ethically while prizing solidarity; to listen and share decisions and managing conflicts by identifying its determinants ${ }^{a}$.

In relation to the ethical and political competencies for nursing practice, the NCG attributes to the educational institution the responsibility to provide students with knowledge and skills so that students are

able to act with a sense of social responsibility and commitment to citizenship, as a promoter of the health of the human being ${ }^{(1)}$.

In accordance with the curricular organization, the NCG suggests aspects that direct a methodology that should be adopted in the process of teaching and learning, considering that, to contemplate the profile of graduates capable of working in different contexts and to promote social transformations necessary, learning should be guided by the methodological principle of action-reflection-action, using as a teaching strategy to resolution of problematic situations ${ }^{(1)}$.

In conformity with the NCG, the curricular structure of nursing courses must ensure, among other aspects, the relationship between teaching, research and extension / service; the definition of teaching strategies that articulate the knowledge, know-how and knowing how to live, and especially, appreciation of ethical and humanistic dimensions, developing attitudes and values oriented towards citizenship and solidarity ${ }^{(1)}$.

Authors who study this theme propose the configuration of comprehensive care as a guideline for change that should be implemented in the formation of health professionals, considering that

if the state assigns the planning for the formation of health professionals to the unified health system (SUS), then SUS should also interfere with the formation orientation consistent with the constitutional guidelines of health ${ }^{(6)}$

Although comprehensiveness of health care, as a SUS principle, is a requirement to guide health professionals' profile development, many authors recognize that teaching programs struggle to promote politicalethical skills during undergraduate courses, trying to

${ }^{a}$ Kurcgant P. The profession - Nursing. The professional - nurse [Lecture in the Course of Nursing Adventist University of São Paulo].São Paulo; 2006. (Portuguese).6. 
focus on comprehensive care, with equity and quality. They attribute this difficulty to the inconsistency in inserting content related to attitudes in educational planning, and especially to the fragility of these competency assessments in student performance. They also consider new opportunities to promote reflection and increase teacher commitment for working across these content areas to be important ${ }^{(6-8)}$.

The International Council of Nurses (ICN) has recently reviewed the international code of ethics for nurses, reaffirming that the need for nursing is universal and that respect for human rights should include cultural rights, the right to life, free choice, dignity and to be treated with respect. ICN standardized ethical conduct for nurses in four elements, related to the people, to nursing practice, to the profession and to the colleagues. For each of them, ICN recommended actions for nurses and managers, educators, researchers and nationwide nursing organizations.

The ICN recommendations for educators were:

To include, in the curriculum, references to human rights, equity, justice and solidarity as the basis for access to care; To introduce concepts related to professional values; To sensitize students about the importance of social action; To promote personal health exemplifying their relationship with other values ${ }^{(9)}$.

The educational institution, as an ideological space, is a scenario where the contradictions between ideal and real, theory and practice, and especially between what is taught and what is learned effectively arise. The former student, as the one who experienced the training process and faced the reality of the job market, can properly explain important aspects that should be considered in the planning and implementation of curricular activities, according to the NCG for nursing courses $^{(1)}$. The aim of the study was to identify politicalethical skills developed during the formative process, experienced by former students from a nursing undergraduate degree course.

\section{METHOD}

This was a qualitative study conducted as a case study with embedded units represented by 32 nurses who graduated in 2003 by a private educational religious institution, who entered the job market in different contexts and at all levels of health care.

Data were collected in the first term of 2006, after approval by the Institutional Review Board of the University of São Paulo School of Nursing (process $487 / 2005)$, according to the ethical standards established by the National Committee for Ethics in Research. The semi-structured interviews were conducted using a script to identify the former students' perceptions regarding aspects that facilitated or hindered the training process during the start of their professional careers.

The former students' statements were analyzed by thematic analysis techniques ${ }^{(10)}$, resulting in the composition of two categories: Political-ethical skills in the formative process and Political-ethical skills as a product of the educational process. The unit of meaning (UM) corresponding to the respective categories was analyzed based on the standards of political-ethical competencies for nurses.

\section{RESULTS}

The socio-demographic characterization of the 32 respondents identified nine male participants with a predominant age group of 27 to 31 years, and 23 females with the majority ranging between 23 to 30 years of age. A total number of 18 participants had a nursing assistant degree before graduation, 26 were attending lato sensu graduate programs, and only one had entered a master's program; 26 had worked in public or private hospitals from middle to high complexity levels of care; 15 had worked in primary health care services; 14 were lecturing in technical schools; only two worked in higher education; and, 25 had experience in more than one workplace. The categories, with their respective UM statements, as highlighted by the objectives of the study, are presented below:

\section{Category 1 - Political-ethical skills in the formative process}

For NCG to substantiate nursing education, politicalethical skills should permeate the teaching proposal and guide the developed activities throughout the educational process ${ }^{(1)}$. We present below the statements on the pedagogical content and strategies that enabled or hindered the development of political-ethical skills, as perceived by former students when they reported their experience in undergraduate education.

\section{UM - The importance of values instruction}

Although former students recognized the difficulty in assessing values incorporation in the unfolding of the educational process, it is clear in their statements that they attributed their achievements in this direction to the university.

College taught me to be very persistent, to take responsibility, something I really enjoyed at that time ... (S18).

The college also gave me ethical-moral support that made me enter the job market with a different perspective ... with a mission to bring comfort to people. This undoubtedly is the great advantage that the college offers to its graduates (E15). 
As a course in an educational institution of a religious character, its mission had the commitment to promote student formation that harmoniously developed their physical, mental and spiritual capacities, promoting the student to practice selfless service. Recognizing the importance of these values, another former student affirmed the intention to use these values in professional practice while participating in the selection process of new nurses.

I think the important values of the university ... As nurses working with continuing education, today we try to filter nurses with a profile compatible to the values that we had at the university (E9).

When working intentionally with the incorporation of humanistic values during undergraduate courses, the school fulfills its social duty. However, it is clear from the content of former students' statements that, in general, they had not received the necessary substrate to consolidate their future professional activities with a political dimension of transformations and achievements geared toward comprehensive health care in its full scope.

\section{UM - The teaching of critical thinking}

The school calendar reserved a space for weekly meetings of cultural character, with all the students of the course, aiming to discuss relevant and up-to-date topics and promote socialization and integration between classes at the same time. From the perspective of former students, this time, although important, was underused.

Since we have this time during the general culture subject, general culture issues actually should be discussed

... most exciting topics for people who have a university degree, who have the capacity to think, to develop critical thinking, considering that we are living in a political crisis in the country. We should have philosophy classes, to learn how to develop more critical thinking in our profession, with qualified teachers (E19).

Through their recognition of the importance of addressing cultural issues and suggesting more updated issues, the students showed that they had appropriated the complex dimension of health education. We argue the need to have, in the unfolding of undergraduate education, a bigger approximation to this theme to support the development of political-ethical competence. Another aspect that emerged in the statements was the qualification of teachers to encourage the development of critical thinking skills for professional practice.

\section{UM - Teaching by the example}

In the statements of some former students, the recognition and appreciation for the teacher who, in the exercise of his/her mission, promoted a sense of responsibility and appreciation of nursing as a profession was noted.
Attitude, good teachers, good mirrors, the notion of what is actually nursing; I think that's what brought real contributions to me (E19).

Despite the curriculum adopted by the school, the professor left an indelible mark on the student when he/she transmitted values that aroused admiration and respect, inspiring confidence in students who manifested the desire to follow the same paths in life. However, it can be asked: was the professor proposing reflection on what direction or model was being taught? What was actually being taught to extend the systemic view on the socio-political scenario, i.e., what was decisive and what was just circumstantial in the living conditions and health of the people?

\section{UM - The teaching of laws}

The legal aspects involving nursing practice were present in all actions performed by nurses in any of their work processes. The student, when faced with the daily reality, referred to the need of addressing nurse practice regulation laws and related themes during undergraduate courses. Nurses' rights and duties, and the definition of their practice, are also themes that interviewees reported had further need for discussion.

Focus on something else related to the profession, on the knowledge of government regulations and institutional laws needed to be focused... Sometimes nurses do not know what are the rights of the nursing team. He does not even know his rights. So, it left nothing to be desired. You will learn it the hard way, because you have not seen ... nobody told you that and if you want to know, you have to chase. This should be a compromise of nursing schools (E6).

The undergraduates of this group experienced a curriculum prior to the NCG, which supplied the student with an early participation in practical settings emphasized on comprehensive care, focusing mainly on hospital settings. In this curriculum the supervised training had not yet been introduced as determined by NCG(1), and the development of management skills was dependent on the opportunities, which sometimes were limited by the lack of reflective performance of nurses or professors who advised the students during practicum.

\section{Category 2 - Political-ethical skills as a product of the educational process}

When reporting the requirements of professional practice as new nurses, former students attached some of the difficulties experienced to the formative process. Despite the intent of the institution to develop in its students a commitment to promote an improved quality of life and health for patients, the development of political-ethical skills, as perceived by interviewees, was represented in the statements that composed the following UM.
Political-ethical skill development in nursing undergraduates Meira MDD, Kurcgant $P$ 
UM - Ethics and the multiprofessional team relationship

The interviewees recognized the interweaving of the technical, ethical and political competence ${ }^{(5)}$. They highlighted, however, difficulties related to the performance of relational aspects in professional practice.

The biggest difficulty is the paperwork of some questions that are so certain and basic in almost all institutions. This work is related to the ethical issue, such as dealing with a professional of your team, the relational part itself ... A little we had, of course, but mostly in theory ... (E2).

The statements regarding this UM bring an important contribution to the redesign of the selection of the themes for the training of political-ethical skills in relationships, especially regarding the exercise of leadership, as considered a priority in nursing education by the interviewees.

\section{UM - The professional reality as the basis for education}

The representation of the interviewees on this aspect of training was significant and reflected the importance of integration between school and health services.

Just in the last year of college we had a vision of how the system works, regarding administrative area, bedside care and bureaucratic tasks, and then we ended up a bit confused ... (S31).

The preparation of students majoring in nursing for the job market should be improved. What is the market should be a focus. To prepare for reality, both in the private sector - considered the top of line - as well as in the public service (E9).

There was a clear and incisive appeal of these and other graduates interviewed for an education that fostered in students, during their undergraduate experience, an experience indicative of the reality of the labor market in different contexts. When the institution facilitated this encounter with different scenarios, it presumably ensured favorable conditions for a practice focused on comprehensiveness and equity of health care.

\section{UM - Commitment to lifelong learning}

Although has been mentioned by only one of the respondents, this is a significant aspect and is worth be mentioned, because shows the commitment of the former students to lifelong learning. Reveal ethical skills of health professionals that, beyond the extention of their occupational space, assemble value to the service inserted around them and guarantees a better assistance/care to the client. The following statement testify how the social commitment of the former students to continue the studies after the graduation.

The former students are always following development, graduations. (S25)
UM - A professional attitude resulting from the educational process

Statements presented by interviewees on the nursing professional attitude strongly appealed to the reflection of political-ethical skill development that should be conducted throughout the undergraduate course, since it would influence the nurses' practical performance.

One thing I will never forget that professors said to us in college is about our posture, the way we speak, our behavior. I realize when I'm acting how involved all of this is, how important it is! Because people come to me and say, Wow! You have a different way of being (E27).

About the question of attitude, I think that the course really gets it, and we see this gap in the job market. Institutions like those professionals trained at college, they prefer them ... the behavior they present in the health units, and even in the matter of clothing (E25).

When evaluating the approach given by teachers on the professional attitude of the nurse during the course, the importance of addressing aspects that may not have been considered in the curriculum, but focused and differentiated the education obtained, was evident in the interviewees' statements.

\section{UM - To be a nurse}

Former students suggested changes in the distribution of content to focus on all dimensions of care, seeking greater coherence and applicability to nursing practice.

The notion of what nursing actually is, I think that is what brought me the greatest contribution, the notion of what nursing is, the concept of nursing ... All is about the care ... To graduate a professional directly involved in care, all of the care process, involving all stages, from bedside assistance to the most bureaucratic task, this is when we have this notion of the roles that define us being a nurse (E19).

\section{DISCUSSION}

The statements highlighted how undergraduates perceived the development of political-ethical skills during the formative process, showing that they realized it to be a result of academic preparation at the undergraduate level. In the first category, Political-ethical skills in the formative process, according to the $\mathrm{NCG}^{(1)}$, the units reinforced that nursing education should be guided toward technical and scientific skill development, enabling a performance based on ethical-political skills, and active and transformative attitudes in different contexts and settings ${ }^{(1)}$. In a design inspired by the theorical framework of Paulo Freire, ethical formation was something essential, and planning a teaching program 
without considering ethics-related aspects was a transgression that reduced the educational experience to mere technical training ${ }^{(11)}$.

The Nursing Undergraduate Course, the object of this study, considered that the proposition of values in a curriculum should influence an existence consistent with the basic principles of Christian ethics, which appreciated the human being as a member of a community, with rights and responsibilities towards the environment, life and family ${ }^{(12)}$. By internalizing these values during undergraduate degree, the nurse students acknowledged in their statements the commitment to act as multipliers. They also highlighted that the ethical and moral responsibility should be present during the educational process and should permeate all teaching actions, once they understood, in a broader context, that this was the basis for an education based on the population's health needs, dedicated to social change ${ }^{(13)}$.

The perception of the professor's role as a reference for students was considered one of the most significant components in the political-ethical education of nurses. It involved knowledge that was not shared in conventional classes, neither was it described in any political-pedagogical project or discipline plan, but rather permeated the whole educational process. This is called the hidden or informal curriculum, which is based on concrete experiences of the key players in the educational process, making the school a living, dynamic and complex place $\left({ }^{14)}\right.$. Social relationships developed between teachers and students constituted one of the sources of the hidden curriculum, based on real problems from the school environment and from teaching practice affecting students and society in general ${ }^{(15)}$.

The role of the professor, at any level of training, required commitment to the student, to the institution and to the society. To fulfill this commitment, beyond the technical-scientific and educational rigor, the teacher also needed dedication, aimed toward the formation of critical citizens and competent professionals ${ }^{(16)}$.

In this formative process laid a political dimension that could not be disregarded, since education was epistemological, directive, therefore political, artistic and moral, using means, techniques and involving frustrations, fears, desires. It was the nature of politics, considered as an quality educational practice for not being neutral ${ }^{(11)}$.

Although the institutions' intention was accomplished in the development of humanistic values, as identified in the graduates' statements, the current socio-political context demanded advances in the educational process to enable the development of politicalethical skills capable of effectively engaging nurses to reflect, propose and demand better working conditions and ensure respect for the patients and worker's rights.
An education ruled by the "anthropo-ethical" concepts comprised a chain of the terms individual/society/species. From these terms emerged the consciousness and the human spirit that goes beyond the moral, for properly humanbased ethics. The anthropo-ethics was the individual consciousness going beyond individuality, and the hope in the fullness of humanity ${ }^{(17)}$. In this direction the following thought was endorsed: Empowering women and men around instrumental knowledge can never be separated from their ethical formation ${ }^{(11)}$.

The need to teach the human condition is defended as a cornerstone for the future of education. The relevance of a reflection that stressed human nature multidimensionality and complexity was integrated into the biophysical and psycho-socio-cultural aspects of mankind, as we developed ourselves beyond the physical world, and the fullness of humanity that occurred in this beyond gap ${ }^{(17)}$. Aware of the complexity of human nature, the interviewees suggested a revision of the educational processes and a redesign of the political-pedagogical project, for a training contextualized to the reality in which the student must enter.

The graduates' statements from the second category Political-ethical skills as a product of the educational process highlighted the importance of an education focused on political-ethical issues for an integral nursing practice. The health professional should be updated on the process of change that permeates society and commit to it consciously and responsibly, seeking when and how to intervene in facts and reality ${ }^{(18)}$.

To cope with the gap that existed between what was learned at university and what happened in reality, the NCG proposed supervised training, with a workload corresponding to $20 \%$ of the total course load, which should be developed in different scenarios and facilitate the interaction with the nurses in clinical practice ${ }^{(1)}$.

As for nurses educating other nurses, the development of skills based on ethical and political values should allow the capacity to act in different areas: such as bedside care, health services, management and nurse education. By doing so, nurses can collaborate in the health policies agenda and this should be an ongoing process that is not finished when one obtains the nursing degree ${ }^{(18)}$. The NCG conferred autonomy to educational institutions regarding the formatting of the curriculum and the design of the course mission, according to the profile of nurses expected ${ }^{(1)}$.

Some former students recognized the purpose expressed in the institutional course mission, which was to educate, within Biblical Christian values, in an integral way of living and excellence in nursing practice ${ }^{(19)}$. They strengthened, however, the need for a deeper reflection about the political mission of the teaching and learning process:

the university fulfills its mission not by developing a discourse on policy, but when, through its educational
Political-ethical skill development in nursing undergraduates Meira MDD, Kurcgant $P$ 
practice, acts preparing citizens for life at the 'polis', for the understanding of the social totality in which citizens are embedded(20).

Training that was focused on specific and essential content for professional practice was a matter of concern that permeated the discussions of authors who advocated a university reform that, to be effective, must take into account the social and political aspects of training, be based on the search for personal success, and the aim for social transformation ${ }^{(21)}$.

During undergraduate study, it is important to create opportunities of conviviality between students and the different agents involved in healthcare processes. While nursing education usually privileges the technical-administrative dimension, its practice requires an understanding of political, economic, ethical and social aspects of health management. To develop these skills, teaching strategies should encourage recognition of the needs derived from the different forms of social organization and the users' life conditions ${ }^{(22)}$.

Such skills are essential in human care in all its dimensions and in any of the nurses practice processes across different settings ${ }^{(23)}$. Thus, for its development, it is essential to implement a teaching program adequate to the current context of health, addressing a training that is:

(...) More open, dialogical, and at the same time critical, more flexible and at the same time more rigorous, firmly grounded in knowledge and based on ethics, focused on the development of reasoning, autonomy, creativity, communication and the ability to identify problems and seek alternatives to overcome them" (24).

\section{REFERENCES}

1. Brasil. Ministério da Educação; Conselho Nacional de Educação, Câmara de Educação Superior. Resolução CNE/CES n. 3, de 7 de novembro de 2001. Institui Diretrizes Curriculares Nacionais do Curso de Graduação em Enfermagem [Internet]. Brasília; 2001 [citado 2012 nov. 23]. Disponível em: http:// portal.mec.gov.br/cne/arquivos/pdf/CES03.pdf

2. Freitas GF, Oguisso T. Ocorrências éticas com profissionais de enfermagem: um estudo quantitativo. Rev Esc Enferm USP. 2008;42(1):34-40.

3. Silva KL, Sena RR. Integralidade do cuidado na saúde: indicações a partir da formação do enfermeiro Rev Esc Enferm USP. 2008;42(1):48-56.

4. Zarafian F. Objetivo competência: por uma nova lógica. São Paulo: Atlas; 2001.

5. Rios TA. Ética e competência. 15ạ ed. São Paulo: Cortez; 2005.
To promote this education, institutions need to reflect critically and rescue the pedagogical dimensions that determined teaching and learning strategies based on the comprehensiveness of health care and equity as an ethical horizon to be pursued in each educational activity.

\section{CONCLUSION}

This study identified aspects to be considered in the educational process for the development of politicalethical skills, such as attitude, values, sense of mission, importance of ethics in the interpersonal relationship of multiprofessional teams, and commitment to lifelong learning and critical thinking. It was possible to correlate teaching of political-ethical skills in the nursing undergraduate degree with the NCG proposals and to identify the role of educators in enabling or hindering this skill development.

Thus, it was clear that education in health fulfilled its mission when, through educational practice, it prepared the student to reflect, understand and participate in the transformation of the society around them. The Nursing Undergraduate Programs, represented by their former students in this study, sought to contribute to this as they advanced in the understanding and implementation of the NCG. It is further considered that the undergraduate courses needed to provide students with experiences of reality that instigated the reflection on the ethical and political health care context where conscious action of the nurse was inserted.

6. Cecin RB, Feuerwerker LCM. Mudança na graduação das profissões de saúde sob o eixo da integralidade. Cad Saúde Pública. 2004;20(5):1400-10.

7. Nosow V, Püschel VAA. The teaching of attitudinal content in higher education of nursing. Rev Esc Enferm USP [Internet]. 2009 [cited 2012 Nov 23];43(n.spe 2):1232-7. Available from: http://www.scielo.br/pdf/reeusp/v43nspe2/en_a15v43s2.pdf

8. Cecilio LCO. Apontamentos teórico-conceituais sobre processos avaliativos considerando as múltiplas dimensões da gestão do cuidado em saúde. Interface Comun Saúde Educ. 2011;15(37):589-99.

9. Conselho Internacional de Enfermeiras(os). Código de Ética do CIE para Enfermeiras(os) revisado em 2012 [Internet]. Genebra; 2012 [citado 2012 dez. 26]. Disponível em: http:// www.icn.ch/images/stories/documents/about/icncode_brazilian_portuguese.pdf 
10. Minayo MCS. O desafio do conhecimento: pesquisa qualitativa em saúde. 11a ed. São Paulo: Hucitec; 2008.

11. Freire P. Pedagogia da autonomia: saberes necessários à prática educativa. 33a ed. São Paulo: Paz e Terra; 2006.

12. Confederação das Uniões Brasileiras da Igreja Adventista do Sétimo Dia. Pedagogia adventista. Tatuí: Casa Publicadora Brasileira; 2004.

13. Faustino RLH, Egry EY. A formação da enfermeira na perspectiva da educação: reflexões e desafios para o futuro. Rev Esc Enferm USP. 2002;36(4):332-7.

14. Giroux H. Teoria crítica e resistência em educação. Petrópolis: Vozes; 1986.

15. Lemos CLS. Explicitando o currículo oculto da clínica integrada. Pesq Bras Odontoped Clin Integr. 2004;4(2):105-12.

16. Frias MAE, Takahashi RT. Avaliação do processo ensinoaprendizagem: seu significado para o aluno do ensino médio de enfermagem. Rev Esc Enferm USP. 2002;36(2):156-63

17. Morin E. Os sete saberes necessários à educação do futuro. 5a ed. São Paulo: Cortez; 2002.
18. Santos SA, Araujo EA. A competência e os aspectos éticopolíticos no curso de enfermagem: a partir do olhar de docentes enfermeiros. ConScientiae Saúde [Internet]. 2008 [citado 2011 dez. 21];7(1):93-100. Disponível em: http:// www.uninove.br/PDFs/Publicacoes/conscientiae_saude/ csaude_v7n1/cnsaudev7n1\%203|45.pdf

19. Centro Universitário Adventista de São Paulo. Projeto Pedagógico do Curso de Graduação em Enfermagem. São Paulo; UNASP; 2001.

20. Rodrigues N. Por uma nova escola: o transitório e o permanente na educação. São Paulo: Cortez; 1985.

21. Buarque C. Uma nova universidade. Ens Superior. 2005;7(78):28-9.

22. Moraes MJB. O ensino de Enfermagem em saúde coletiva: redescobrindo caminhos para novas práticas [dissertação]. São Paulo: Escola de Enfermagem, Universidade de São Paulo; 2003.

23. André AM, Ciampone MHT. Competências para a gestão de Unidades Básicas de Saúde: percepção do gestor. Rev Esc Enferm USP. 2007;41(n.esp):835-40.

24. Pinhel I, Kurcgant P. Reflexões sobre competência docente no ensino de enfermagem. Rev Esc Enferm USP. 2007;41(4):711-6. 